\title{
A RELAÇÃO ENTRE PAISAGEM, PRODUUÇÃO E HABITAÇÃO DE UM ENGENHO \\ NA ILHA DE SANTA CATARINA: \\ PROPOSTA PARA APLICAÇÃO EM \\ INTERPRETAÇÕES ARQUEOLÓGICAS
}

Osvaldo Paulino da Silva*

\section{1 - INTRODUÇÃO}

Os engenhos de farinha de mandioca e de cana de açúcar surgem num momento complexo para a história da colonização açoriana iniciada em meados do século XVIII, na ilha de Santa Catarina. Orientados pelo governo português a se instalarem como agricultores, os imigrantes se viram diante de culturas infrutíferas, como por exemplo o trigo e o algodão. ${ }^{1}$ Com o insucesso destas culturas, tidas como prioritárias pelo governo colonial, os novos colonos encontraram no cultivo da mandioca uma fonte segura de sobrevivência.

$\mathrm{O}$ aumento significativo do plantio e colheita da raiz da mandioca, o conhecimento técnico sobre mecanismos de moagem de grãos nas azenhas, atafonas e moinhos de vento trazido na bagagem dos recémchegados imigrantes e a experiência há muito tempo adquirida pelas

* Mestrando do curso de Pós-Graduação em Arqueologia da PUC/RS.

1 CABRAL, Oswaldo R. Os açorianos. Florianópolis: Imprensa Oficial, 1950. p. 40-41. 
populações ilhoas na técnica de produção de farinha de mandioca em engenhocas manuais, proporcionaram o aparecimento de centenas de engenhos espalhados por toda a ilha ainda no século XVIII, ${ }^{2}$ tornando a cidade de Desterro, antiga Florianópolis, num dos maiores pólos exportadores de farinha de mandioca no Brasil, no início do século XIX. ${ }^{3}$

Os engenhos possibilitaram o aparecimento da indústria rural, responsável não só pela produção de farinha, mas de açúcar e de aguardente de cana. Os ranchos de engenhos incorporaram-se na paisagem ilhoa. As pessoas utilizavam-nos também como residências provisórias ou definitivas. Neles trabalhava toda a família, inclusive as crianças e eventualmente algum escravo, se a família o possuísse. Quem não tinha um engenho, podia trabalhar por arrendamento ou em troca dos produtos. A farinha passou a fazer parte da dieta como principal produto na mesa do habitante ilhéu. ${ }^{4}$ Tornou-se o meio de sustento de muitos habitantes da ilha de Santa Catarina.

Eram construídos com os materiais que a natureza oferecia em abundância, geralmente utilizando-se a técnica de "pau-a-pique", não obstante a existência de outras técnicas construtivas, porém menos comuns. Como força motriz, a tração animal foi a que melhor se adaptou. Nela, o boi foi o animal que melhores condições oferecia, devido sobretudo a sua resistência.

Entretanto, com a mesma rapidez que surgiram, foram desaparecendo já em meados deste século. Se os engenhos encontravam-se numa fase de decadência na década de 1960, a especulação imobiliária iniciada nesse período de forma expressiva na ilha de Santa Catarina, foi o golpe de misericórdia. Para dar lugar à casas de veraneio, sítios, residências ou simplesmente para "limpar" o terreno, muitos engenhos tiveram seus já frágeis ranchos derrubados, seus artefatos laboriosamente entalhados à

2 Estatísticas de 1794 apontam cerca de 382 engenhos de farinha de mandioca e mais de uma centena de engenhos de cana de açúcar em produção na ilha de Santa Catarina, em documento do Arquivo Ultramarino em Portugal, citado por Nereu do V. PEREIRA, no artigo " A origem e a tecnologia dos engenhos de farinha da ilha de Santa Catarina" In: Anais da Segunda Semana de Estudos Açorianos. Florianópolis: UFSC, 1987. p. 252.

3 PIAZZA, Walter F. A mandioca e a sua farinha: aspectos culturais na Ilha de Santa Catarina. Florianópolis: Faculdade Catarinense de Filosofia, 1956, p. 16.

4 A farinha de mandioca possui uma considerável diversidade alimentícia. Prepara-se com ela o tradicional "pirão", com água quase fervente, café ou caldo de feijão ou ainda bolinhos que podem ser doces ou salgados. Antes de ser forneada a massa da mandioca permite outras especialidades que são o "biju" e o "cuscuz". 
mão em madeiras nobres, vendidos como objetos de decoração ou abandonados no tempo. A maioria dos ranchos que resistiram foram reutilizados como garagens, estábulos, galpões ou abandonados à própria sorte, corroídos pelo tempo ou destruídos para reaproveitamento de alguns de seus materiais construtivos. Dos engenhos abandonados, restam poucos vestígios ou somente a lembrança por parte daquelas pessoas que de uma forma ou de outra neles se envolveram, vivenciando seu cotidiano. Estes, distribuem-se por todo o território ilhéu, constituindose num valioso patrimônio arqueológico, com grande potencial de pesquisa. $^{5}$

Com o objetivo de melhor interpretar o resultado de investigações arqueológicas que futuramente ocorrerão nestes sítios, optou-se pela observação de um engenho ainda em funcionamento, mas que mantivesse o menor número possível de modificações nas técnicas rudimentares muito utilizadas por mais de duzentos anos em toda a ilha. Mesmo diante do quadro descrito acima, de engenhos destruídos por toda parte, havia ainda alguns raros em funcionamento. Destes, a maioria já estava operando com motores movidos a energia elétrica ou a óleo diesel. Mas havia um, na parte sul da ilha, que ainda mantinha seu processo de produção e estrutura habitacional dentro de parâmetros considerados satisfatórios para se alcançar o objetivo deste trabalho. $\mathrm{O}$ engenho é de propriedade de Francisco Tomás dos Santos, que ali vive e trabalha há mais de sessenta anos. Daqui em diante, Francisco será tratado apenas de "Chico", que é seu apelido com o qual gosta de ser chamado.

As observações e coletas de dados foram realizadas em três dias do mês de novembro de 1993, possibilitando o registro de quase todas as atividades produtivas e domésticas lá desenvolvidas. Com exceção das lides ligadas à produção de farinha de mandioca, que ocorre entre os meses de maio e julho, foram presenciadas as atividades que vão desde o plantio da cana de açúcar em roças previamente preparadas, até a destilação da cachaça, evidentemente porque o proprietário dispõe de várias roças em diferentes estágios do ciclo agrícola.

A observação do trabalho nas roças, da distribuição destas na paisagem e da utilização e reutilização da própria paisagem, mostrou a interdependência existente entre homem e meio ambiente. Neste contex-

5 Pesquisas nesse sentido estão sendo desenvolvidas pelo autor deste trabalho, a nível de mestrado, tendo como temática central "Arqueologia dos engenhos da ilha de Santa Catarina", que inclui um mapeamento de todos os sítios de engenhos encontrados naquela regiâo. 
to foi possível identificar sistematicamente um modelo de atividades especializadas e de freqüência de circulação nas áreas fora do engenho. No engenho e seu entorno as atividades especializadas foram também identificadas como forma de manter a estrutura funcional do conjunto tanto na área de produção quanto na área doméstica, dando origem a áreas com freqüência de circulação diferentes.

\section{2 - O ENGENHO DO CHICO}

\section{1 - $O$ engenho na paisagem}

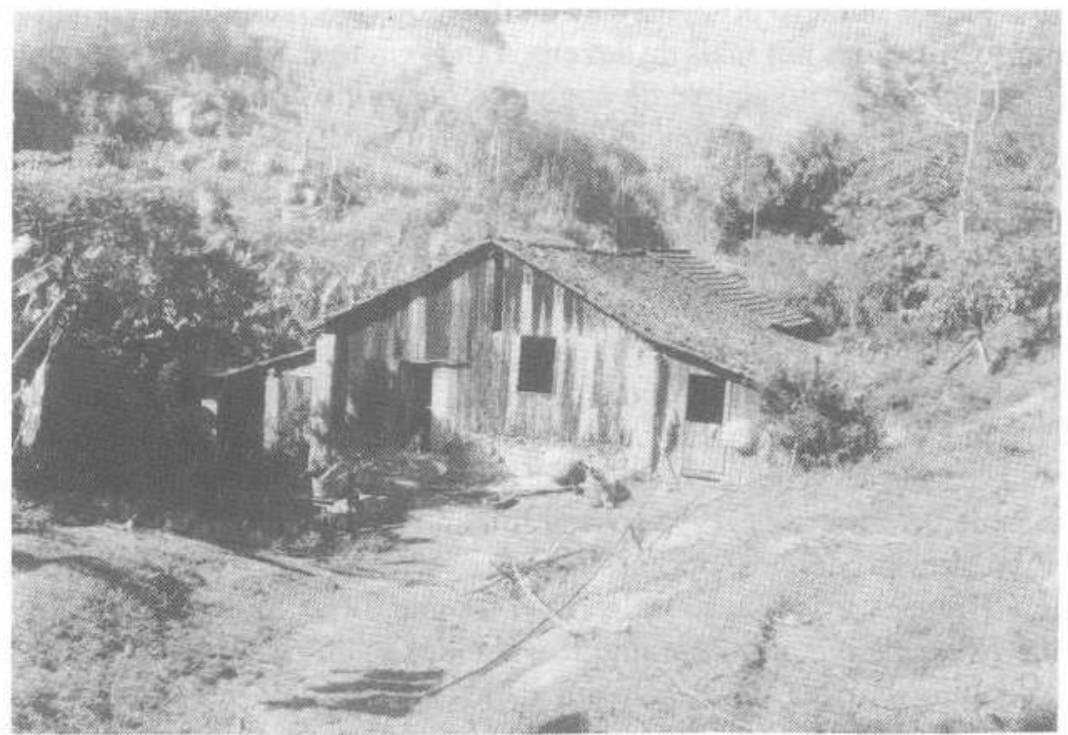

Engenho do Chico - roças e vegetação secundária no seu entorno.

O engenho do Chico situa-se na localidade de Costeira do Ribeirão, numa área conhecida como Sertão do Peri, Distrito de Ribeirão da Ilha, no município de Florianópolis. A paisagem natural, caracterizada pela topografia bastante acidentada, é composta por morros cristalinos que oscilam até 440 metros de altura do nível do mar, cobertos atualmente 
por algumas pastagens decorrentes de desmatamentos e por vegetação secundária em vários estágios de sucessão espontânea. Nesta sucessão, as herbáceas ocupam a etapa inicial, seguida da "capoeirinha" onde predominam os vassourais, da "capoeira", composta por arbustos e árvores de médio porte e do "capoeirão" formado por árvores de grande porte na sua maioria, e imediatamente anterior à "mata secundária", último estágio da regeneração natural. ${ }^{6}$ As áreas onde ocorrem estes estágios são oriundos principalmente de roças abandonadas pela infertilidade do solo. Remanescentes da mata primária, a Floresta Pluvial de Encostas, encontram rarefeitos pela região, ocorrendo apenas naqueles locais por demais íngremes, onde a ocupação agrícola teria sido infrutífera.

O engenho está construído numa área de encostas voltadas para a lagoa do Peri, no seu lado oeste, distando dela uns mil metros aproximadamente. Mantém-se ligado à estrada principal da localidade por uma trilha, utilizada apenas por carros de bois ou veículos bem tracionados, tipo "jipe". Esta trilha possui uma extensão de aproximadamente 1 quilômetro e meio até o engenho, com algumas porteiras e "cancelas" na sua extensão. Em alguns pontos ela desaparece, misturando-se com os campos de pastagens e com o gado solto, retomando seu curso mais adiante.

O relativo isolamento em que se encontra o engenho não constitui um caso à parte. No passado, não havia a rede de estradas que há hoje. Os núcleos habitacionais nas freguesias eram interligados por trilhas, muitas delas desaparecidas, outras transformadas nas atuais estradas, seja em trechos ou na totalidade de sua extensão. Algumas construções muito antigas na localidade de Costeira do Ribeirão por exemplo, não estão nem próximas e nem de frente para a estrada atual, contrariando o posicionamento comum de construções mais modernas, sempre com a fachada principal voltada para a estrada. Nas proximidades do engenho, há vestígios de uma trilha de carros de boi que parece levar a lugar nenhum atualmente, o que indica que por ali deveria passar um caminho com um considerável movimento de carros de bois ou utilizada por muito tempo, a se julgar pela profundidade dele. Estas trilhas se tornavam muito comuns à medida que as roças de mandioca ou de cana de açúcar distanciavam-se dos engenhos. Para o transporte da roça até o engenho,

6 CARUSO, Mariléa M. L. O desmatamento da Ilha de Santa Catarina de 1500 aos dias atuais. 2. ed. Florianópolis: UFSC, 1990, p. 115. 
eram utilizados meios de transporte apropriados para as acidentadas áreas rurais: o carro de bois, e derivado deste, o "carretão", um carro também puxado por bois, mas com as rodas bem menores e uma espécie de barrote de madeira arrastando ao chão, necessário para diminuir a velocidade nos caminhos muito íngremes.

Os recursos hídricos são reduzidos. Não há na região, rios volumosos, mas apenas pequenos córregos pedregosos que convergem para a lagoa do Peri, para o Oceano Atlântico ou para a Baía Sul. Entretanto, mesmo tendo pouco volume d'água, estes córregos foram fundamentais na instalação dos engenhos na ilha de Santa Catarina.

A lagoa do Peri é um grande reservatório natural de água potável, mas devido à dificuldade de acesso, Chico não demonstra interesse em explorar seus recursos, no sentido de pesca e transporte. Para abastecimento d'água, há um pequeno córrego que passa há alguns metros do engenho, o suficiente para suprir suas necessidades.

Atualmente, todas as terras do engenho do Chico encontram-se dentro do Parque Municipal Lagoa do Peri, área de preservação ambiental onde são proibidas tanto a caça de espécies faunísticas quanto a derrubada da vegetação nativa. ${ }^{7}$

\section{2 - A tipologia arquitetônica}

A técnica construtiva mais utilizada na construção dos engenhos na ilha de Santa Catarina, foi a de "pau-a-pique". Os engenhos eram construídos com os materiais que a própria natureza oferecia em abundância. Troncos para os esteios e madeiramento superior, ripas e barro para as paredes, pedras para o alicerce e folhas de tiririca para a cobertura, era tudo o que se necessitava para levantar um engenho. No final do século XIX, V. VÁRZEA descreve os engenhos de farinha de mandioca e de cana de açúcar "... numa espécie de vasto rancho com paredes de pau-a-pique barreadas e as mais das vezes coberto de tiririca". ${ }^{8}$ Já na década de 1950, W. PIAZZA, dá uma descrição semelhante aos engenhos que naquela época estudou: "As casas de engenho da Ilha que visitamos ou eram de paredes de tijolos raramente caiadas, e que cons-

7 O Parque Municipal Lagoa do Peri foi criado pela lei municipal número 1202 , de 02 de abril de 1974 e tombado pelo decreto número 1408, de 04 de junho de 1976.

8 VÁRZEA, Virgílio. Santa Catarina, a Ilha. Florianópolis: IOESC, 1984, p. 202. 
tituem a exceção, excepcionalíssima, ou eram de madeira ou ainda eram de ripas argamassadas de barro que constituem a maioria". ${ }^{9}$ Esta foi a técnica utilizada para construir o engenho do Chico. Segundo seu proprietário, o engenho teria sido construído por seu avô nos últimos anos do século passado e reformado anos mais tarde, conservando até hoje o aspecto da reforma. Nela, foram introduzidas tábuas planas nas paredes, em substituição às paredes salpicadas de barro. Os esteios foram trocados por pesados pilares de pedra e tijolos argamassados com barro. $\mathrm{Na}$ cobertura, foram utilizadas telhas de barro, do tipo capa e canal. As aberturas, assimetricamente dispostas, utilizaram tábuas planas, porém bastante irregulares. O madeiramento superior, parece não ter sido modificado, pois ainda conserva marcas da utilização em outra construção. Segundo Chico, foi proveniente do desmonte de um engenho anterior ao seu, pertencente a sua família. $O$ piso ainda conserva o "chão-batido" em quase todas as áreas do engenho. Exceção ao conjunto, encontra-se a "casa de moradia", que será tratada mais adiante.

A técnica de "pau-a-pique" foi a mais comum usada na ilha de Santa Catarina na construção de engenhos, mas não foi a única a ser utilizada. Outras técnicas, utilizando-se de outros materiais construtivos também marcaram presença, entre elas, a construção toda de alvenaria, com tijolos, pedras e argamassa de barro, cal e areia. Esta, destinava-se certamente às pessoas mais abastadas.

\section{3 - A tipologia e a função dos maquinários e artefatos produtivos}

O maquinário utilizado no engenho do Chico é todo confeccionado em madeira e artesanalmente, por mestres artífices especializados. Segundo Chico, toda a madeira utilizada foi cortada ali, na própria região, na época que ainda havia maiores concentrações de mata nativa. $\mathrm{O}$ maquinário de produção de farinha de mandioca é chamado de "engenho de cangalha", composto por uma grande roda dentada, que funciona como uma roda mestra, posta horizontalmente sobre um eixo perpendicular ao teto do rancho. Acoplada verticalmente a ela, há outra roda, chamada de "roda sevadeira", responsável pela trituração da raiz da mandioca. A roda mestra também aciona a "hélice" ou "pá de abanar",

9 PIAZZA, op. cit., p. 25. 
FRANCISCO TCMAS DOS SANTOS
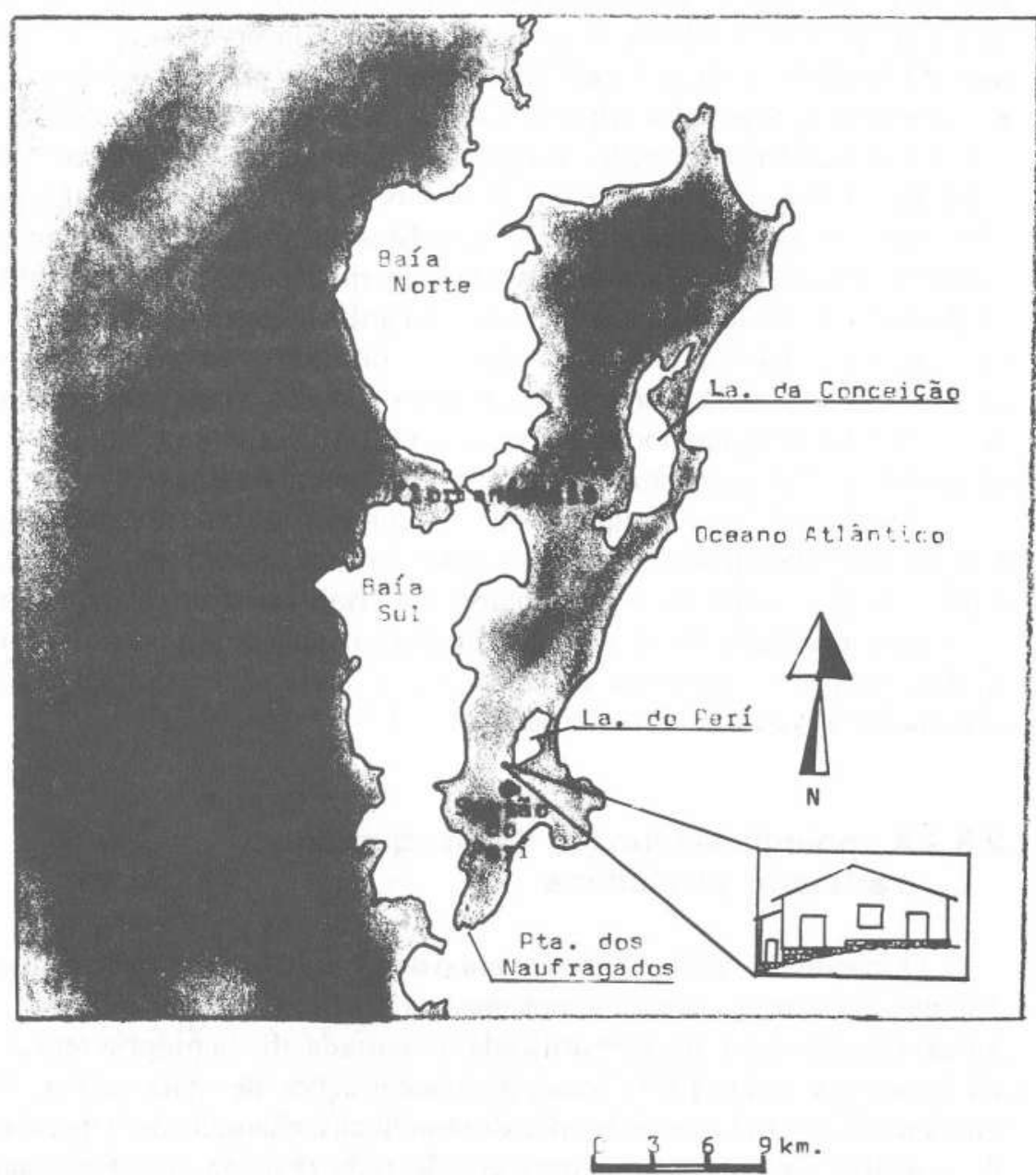

ESCALA 
responsável pelo movimento da farinha que está sendo "forneada", evitando assim que ela passe do ponto, o que alteraria tanto a cor quanto o gosto, tradicionais. Todo o conjunto é movimentado pela força de um boi, que movimentando-se ao redor de todo o equipamento, faz girar a roda mestra, através de um braço, chamado de "almanjarra".

Ao lado deste conjunto, situa-se a prensa, composta por uma pesada trave, uma base e três fusos, todos de madeira, sem um único prego. Estas peças são responsáveis pelo esmagamento e secagem da massa de mandioca, colocada em uma espécie de cesto de fibras vegetais, chamado de "tipiti". Ainda como artefatos auxiliares, existem dois cochos também de madeira, utilizados na recepção da massa de mandioca sevada e da farinha já forneada.

O maquinário do engenho de açúcar é quase todo confeccionado em madeira. Apenas uma fina cobertura metálica é utilizada nos cilindros moedores, introduzida recentemente.

A moenda é composta por três grandes cilindros de madeira acoplados verticalmente. O cilindro do meio aciona os outros dois através de dentes entalhados na sua parte superior. Está ligado a um eixo perpendicular ao teto e apoiado no chão, sobre uma pedra. Da parte superior do eixo partem as duas almanjarras onde são cangados os dois bois necessários à movimentação do conjunto. Este conjunto, conhecido como "moenda de entrosas", ${ }^{10}$ é responsável pelo esmagamento do caldo da cana. Sob a moenda há uma mesa retangular, utilizada no suporte da cana que entra nos cilindros e do bagaço que é reintroduzido para melhor aproveitamento do caldo. Sob a mesa há uma pequena calha, ligada a um tubo de bambu que conduz o caldo da cana até os cochos de recepção e fermentação .

\section{4 - $O$ produto do engenho}

O engenho do Chico possui os aparatos de produçâo de farinha de mandioca e de açúcar e derivado deste, um alambique, que atualmente é o principal meio de sustento do engenho, embora a farinha seja também ali produzida, mas só nos meses de junho e julho. A produção de açúcar está atualmente desativada, mas este aspecto não chega a mudar substancialmente as atividades desenvolvidas no engenho, em relação à

10 AZEVEDO, Esterzilda B. De. Arquitetura do açúcar. São Paulo: Nobel, 1990. p. 59. 
produção de aguardente. No dois processos, a última etapa é que se diferencia uma da outra. Para produzir açúcar, o caldo da cana é conduzido às caldeiras para se transformar em melado e depois, cristalizar-se em açúcar. Na produção de cachaça, o caldo de cana é fermentado por alguns dias e depois conduzido ao alambique, para depois de 4 horas aproximadamente, se transformar em aguardente pelo processo de destilação. A cachaça obtida é vendida na localidade mais próxima ou no próprio engenho, a visitantes que ali aparecem, principalmente nos fins de semana.

Além da cachaça e da farinha de mandioca, são produzidos nos engenhos, outros gêneros de subsistência, principalmente de origem agrícola que mantém quase todas as necessidades das pessoas que ali vivem.

Todo o trabalho no engenho é executado normalmente por duas pessoas. Chico, que é um dos sete herdeiros do engenho e suas terras e Alaíde, uma mulher de aproximadamente 90 anos - ela própria não sabe mais a sua idade exata - que ali vive há cerca de 30 anos.

\section{5 - Divisão de tarefas especializadas}

A divisão de tarefas especializadas no engenho do Chico obedece a uma característica peculiar: a falta de mão de obra decorrente do abandono de todos os seus irmãos da atividade rural. Assim, a sobrecarga para os que ficaram influenciou de forma fundamental na diminuição da produção. Chico cuida da roça, desde a derrubada da vegetação até a colheita e o transporte da cana para o engenho. Na roça, o trabalho requer especialização. O plantio da cana obedece certos meses do ano; as mudas são replantadas com uma distância de aproximadamente 40 centímetros de distância uma das outras; há períodos certos para a roça ser capinada, geralmente 3 vezes no ciclo agrícola da cana - cada ciclo equivale a dois anos. A não obediência a este critério implicaria em capinar mais vezes, pois as ervas que nascem quando as canas ainda são pequenas, floresceriam e espalhariam suas sementes, germinando mais tarde quando a roça já havia sido capinada normalmente.

As atividades agrícolas estendem-se também ao plantio de mandioca, feijão, banana e outras culturas de subsistência, todas exigindo cuidados de manutenção. 
Junto ao trabalho na roça, Chico mantém um controle mais rígido sobre os bois que movem o moedor de cana. Por exercerem muito esforço físico, os bois necessitam de melhor alimentação. São amarrados junto a um local com pastagens mais abundantes e mudados deste local pelo menos três vezes ao dia, para novos locais de pastagens.

No engenho, as atividades se diversificam em função dele abrigar um sistema de produção e outro de habitação. Alaíde ocupa-se das atividades domésticas. Prepara comida, lava roupas e utensílios, mantém limpo o chão do engenho, cuida das galinhas e porcos e eventualmente, sobe alguma colina para mudar os bois.

A moagem da cana é executada normalmente à noite, envolvendo as duas pessoas do engenho.

Algumas atividades no engenho, que exigem menor esforço físico, são efetuadas por Alaíde, embora Chico saiba também fazê-las, mas que normalmente não dispõe de tempo. Ela controla a fermentação do caldo e da destilação. Esta é uma das tarefas mais especializadas do engenho, pois é preciso exercer um controle rígido sobre o fogo no alambique. Deve ser sempre brando e contínuo, caso contrário comprometerá a qualidade da cachaça. Além disso, os primeiros vapores alcoólicos que se desprendem do caldo, são mais fortes e os últimos são mais fracos. É preciso saber exatamente a hora de interromper o processo.

A vida num engenho onde trabalham apenas duas pessoas pode parecer duríssima numa primeira impressão, mas quando se conhece a estrutura funcional, baseada na divisão de tarefas e na organização delas durante o dia, muda-se logo esta impressão. Tudo isto funciona sem um esquema escrito, sem obrigação, apenas a espontaneidade e a tradição de quem vem desenvolvendo essas atividades durante toda a vida, que aprenderam com seus pais que por sua vez aprenderam com seus avós...

\section{6 - Possibilidades de um modelo etnoarqueológico}

Este tópico não pretende manter um discurso sobre a aplicação das comparações etnográficas em arqueologia. $\mathrm{O}$ assunto é muito amplo e teorizar neste sentido seria praticamente inesgotável. O objetivo, é fazer algumas considerações sobre o uso desta nova abordagem na arqueologia e apresentar os resultados das observações efetuadas num engenho como proposta para aplicá-las futuramente em interpretaçóes de dados arqueológicos de sítios de engenhos, essencialmente na ilha de Santa Catarina 
e adjacências, onde a instalação e o uso destes locais de produção de farinha de mandioca, açúcar e cachaça tornaram-se peculiares.

A etnoarqueologia tem sido tradicionalmente utilizada na arqueologia pré-histórica, para quem tem trazido excelentes resultados, quando é corretamente aplicada. A comparação etnográfica entre duas sociedades, uma vivente e outra passada, portadoras do mesmo desenvolvimento tecnológico, tem muito ajudado os arqueólogos que optam por esta abordagem, na difícil tarefa de compreensão dos dados arqueológicos. Entretanto a utilização de paralelos etnográficos corre o risco de falsear as informações obtidas se não forem utilizados cautelosamente. As sociedades atuais estudadas, por mais "primitivas" que sejam, não possuem um invólucro que as separa dos tempos modernos. Alguma mudança, por menor que seja, que pode ter ocorrido ao longo dos anos, tem de ser levada em conta. No engenho do Chico, os três cilindros da moenda foram cobertos por uma fina chapa de ferro, para melhor esmagar a cana. Como isto foi uma inovação recente, as antigas moendas que utilizavam a superfície de madeira, facilmente desgastáveis, tinham uma produção menor e consequentemente um tempo maior gasto na operação do esmagamento da cana para se obter a mesma quantidade de caldo que se obtém atualmente. A estrutura funcional pode modificar-se, ainda que de maneira leve. Embora seja impossível encontrar num engenho atual, a mesma estrutura funcional de um engenho do século XVIII, as diferenças podem ser devidamente "controladas".

As comparaçōes etnográficas podem trazer resultados satisfatórios à arqueologia histórica à medida que houver um realinhamento, feito pelo arqueólogo, entre as duas sociedades estudadas. A influência que o meio ambiente exerce na obtenção de recursos naturais comporta-se como uma variável fundamental no estudo destas sociedades.

No sul de Portugal, num exemplo de aplicação da etnoarqueologia para se entender grupos humanos modernos, T. J. GAMITO obteve bons resultados na comparação etnográfica dos vestígios arquitetônicos de uma aldeia ocupada pelos mouros no início deste milênio, com uma outra aldeia fundada no mesmo período, mas que se mantém até hoje, ainda que pese o complexo aspecto religioso naquele contexto. ${ }^{11}$

11 GAMITO, Teresa J. Aldeia dos Mouros versus Alcaria Queimada: an ethnoarchaeological case study. In: . Arqueologia hoje I. Faro: Universidade do Algarve, 1990. p. 266-280. 
O engenho do Chico, com 250 metros quadrados de área construída é atualmente um caso atípico na relação espaço-pessoas. É excessivamente grande para abrigar apenas duas pessoas. Entretanto, já moraram e trabalharam ali, 12 pessoas, número para o qual ele foi construído.

O abandono de que o engenho foi vítima a partir da década de 1960, não foi um caso isolado. Neste período, tem início um processo de decadência na produção nos engenhos tendo como causa vários fatores. Um dos mais contundentes, a especulação imobiliária, já tratado neste trabalho, deu origem à pouca disponibilidade de terras acessíveis para o plantio. Com o aparecimento de fecularias e usinas, a produção em escala industrial da farinha e do açúcar, já ensacados em pequenas porções, geralmente de 1 quilo, torna-os mais práticos e acessíveis ao consumidor, além de, eventualmente terem um preço menor. Um modismo muito comum nesse período foi a decoração de casas, pátios, jardins, e empresas com os pesados artefatos dos engenhos, principalmente dos engenhos de farinha. Seus fusos, prensas, rodas dentadas e outros possuíam valores consideráveis no mercado de antigüidades, levando um proprietário de engenho já em franca decadência a vender todo o seu maquinário. $\mathrm{O}$ crescimento populacional leva o proprietário a destinar parte de suas terras, a maior parte às vezes, a seus filhos como herança, ocorrendo uma pulverização das áreas cultiváveis, que já eram pequenas. ${ }^{12} \mathrm{O}$ aumento da área urbana do município de Florianópolis atraiu trabalhadores para a construção civil, bancos, lojas e para a prestação de serviços. A debandada da área rural provoca a descontinuidade profissional. Os filhos dos agricultores mantêm a área rural apenas como residência. A maioria dos engenhos operava em condições precárias de recursos humanos. Seu proprietário, muitas vezes em idade avançada, se via na impossibilidade de manter as poucas roças em condições de plantio e colheitas, optando pela desativação do engenho. Não tinha ninguém para trabalhar ou o engenho não dava lucros é atualmente, a queixa comum entre aqueles que eram proprietários, quando são questionados sobre a desativação de seus engenhos.

Diante destes fatores, o registro arqueológico em formação, resultante das atividades em franca decadência no engenho do Chico, ocorreu também na maioria dos engenhos ilhéus que hoje estão desativados ou

12 A agricultura na Ilha de Santa Catarina sempre foi caracterizada pela pequena propriedade, tendo seus antecedentes na distribuiçāo de terras aos açorianos no início da colonização. 
deles restam apenas vestígios. A diminuição brutal da mão de obra especializada que antecedeu ao abandono total ocorreu praticamente em todo o território ilhéu.

Os dados etnográficos observados no engenho do Chico podem explicar as questôes advindas da necessidade de interpretação de modelos comportamentais de um engenho do século XIX, por exemplo. Naquele engenho não se observa um desenvolvimento tecnológico capaz de alterar possíveis modelos abordados. As duas pessoas que ali vivem, resistem na introdução de inovações, mesmo que possa lhes trazer benefícios imediatos. Quando uma rede de energia elétrica passou perto dali, não houve interesse do proprietário em instalá-la no engenho. Um lampião a gás emprestado por um amigo, simplesmente foi devolvido porque ofuscava a visão à noite.

A estagnação ali verificada se por um lado manteve técnicas primitivas inalteradas, responsáveis por baixos níveis de produção se comparados com equipamentos modernos de moagem da cana por exemplo, por outro conservou inúmeros aspectos fundamentais na compreensão dos meios produtivos tradicionais em engenhos na ilha de Santa Catarina.

O registro arqueológico é por essa maneira, explicado e dotado de significados obtidos a partir de grupos humanos atuais. ${ }^{13}$ A sobreposição de duas etapas temporais - uma vivente e outra passada - permitirá melhor visualização do processo de acumulação de depósitos arqueológicos, num processo de produção econômica que mantém-se quase inalterado por mais de duzentos anos.

\section{3 - O ESPAÇO INTERNO}

\section{1 - O funcionamento da casa da moenda}

A casa da moenda constitui-se num espaço fundamental no ciclo produtivo da aguardente e do açúcar. No engenho do Chico, é o maior de todos os espaços, com 93 metros quadrados (ver mapa 2). Requer o trabalho especializado de duas pessoas: a que introduz a cana entre os

13 BORRERO, L. A.; YACOBACCIO, H. D. Etnoarqueología de Asentamientos Aché. In: Journal de la Société des Américanistes. Buenos Aires, 1990. p. 7-33, p. 8. 
CRGANIZAÇ⿻ E DIVISR̃C DO ESPAÇO INTERWO

$$
\text { B - Produgăb }
$$

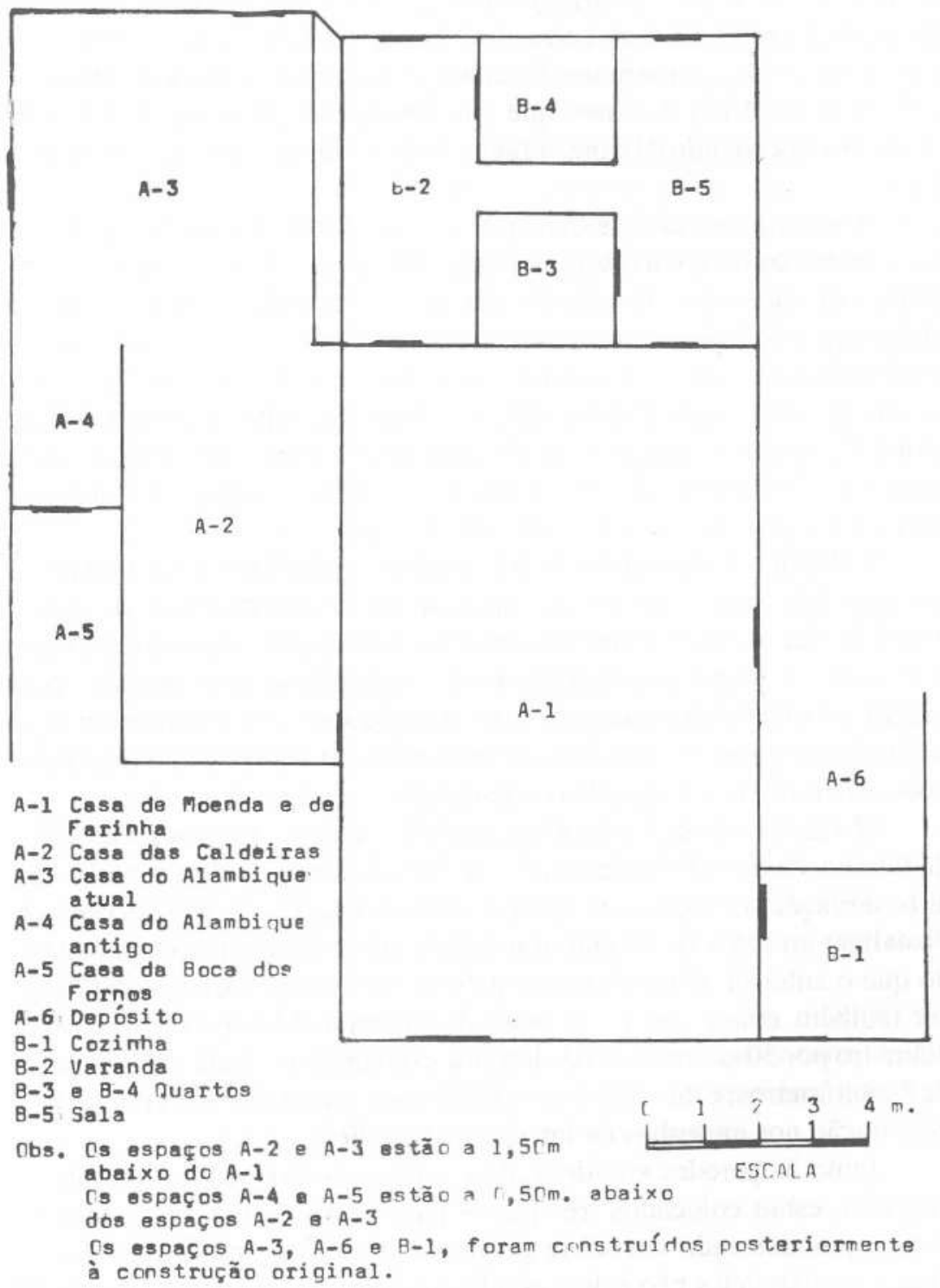


cilindros e a que retira o bagaço do outro lado do cilindro, reintroduzindo para obter maior quantidade de caldo. O trabalho na moenda é executado de pé e de frente para o cilindro do meio, tanto de um lado quanto do outro. Esta atividade leva cerca de 2 horas ininterruptas, geralmente à noite e duas vezes por semana. Com isso, Chico obtém aproximadamente 400 litros de caldo de cana, que vão lhe render perto de 50 litros de cachaça, dependendo da cana, ou seja, as mais doces são as que produzem mais.

A moenda é movimentada por dois bois que deixam ao seu redor um registro arqueológico singular: um círculo perfeito no chão, com 4,80 metros de diâmetro, através de um sulco chamado "andame", de 50 centímetros de largura e profundidade que varia à medida que vai sendo entulhado pelo bagaço de cana triturado pelas patas dos bois e propositadamente pelo barro depositado, para que não fique muito profundo, afinal de contas são dois bois de aproximadamente 700 quilos cada, passando pelo mesmo local a cada 12 segundos, durante 4 horas por semana, ou seja, 1.200 vezes por semana, cada boi.

O diâmetro do círculo é condicionado ao tamanho das almanjarras que prendem os bois à moenda. Como este tamanho é padrão, pelo menos no sul da ilha de Santa Catarina, o modelo serviria não só para identificar o tipo de engenho em escavações arqueológicas, mas também para localizar exatamente onde as pessoas trabalhavam junto ao moedor, pois o cilindro do meio serve de base como ponto central do círculo feito pelos bois. Além disso, serviria de referência para os demais espaços.

No mesmo espaço e nível da moenda, acha-se instalado o aparelho de fabricação da farinha de mandioca. Nos dias em que foram realizadas as observações no local, este aparelho estava desativado, mas foi possível visualizar ao redor do mesmo um círculo no chão, com diâmetro maior do que o anterior, evidentemente pelo conjunto de produção de farinha ser também maior que o conjunto da moenda. Medindo 6 metros de diâmetro por 50 centímetros de largura, com profundidade que não passa de 5 centímetros, este sulco é produzido apenas por um boi, responsável pela tração nos engenhos de farinha de mandioca.

Junto às paredes que delimitam a casa da moenda do restante do engenho, estão colocados três paióis para armazenamento de farinha. Estão apoiados cada um sobre pequenos troncos de madeira. Como o chão embaixo deles não é desgastado por limpeza ou por uso, apresenta desníveis em relação ao restante do piso. Isto certamente traria dúvidas numa decapagem de níveis de ocupação numa escavação arqueológica 
Periodicamente, o engenho sofre varreduras, à medida que se acumulam detritos no chão. Este hábito cria áreas de acumulação de materiais descartados fora dos limites do espaço interno. ${ }^{14} \mathrm{~A}$ vassoura utilizada é confeccionada com ramos de "vassoura", apanhados nas redondezas e amarrados numa vara de bambu. Quando secos, produzem maior atrito ao chão, aumentando o desgaste da superfície do piso. $\mathrm{Na}$ área junto à entrada principal vivem dois cães. Estes animais constituemse numa variável importante na formação do registro arqueológico de restos alimentares de origem animal. Eles comem grande parte dos ossos descartados de aves e pequenos animais. Num dos dias da observação, havia peixe na refeição principal. Quando jogados fora, os ossos foram devorados pelos dois cães. No dia seguinte, eles receberam propositadamente, dois ossos de bovino, cada um com aproximadamente meio quilo. Ao receberem os ditos ossos, os cães roeram-nos por algum tempo e em seguida enterraram-nos em local próximo do engenho. Por outro lado, intervém no espaço interno do engenho, cavando buracos para se acomodarem.

Outra questão levantada na casa da moenda foi a existência de dois locais de antigos fogões. Aparentemente, pareciam ter sido utilizados simultaneamente, mas segundo informações do proprietário, eles faziam parte da antiga cozinha existente naquele local. Um deles teria sido construído junto com o engenho e o outro, construído quando o anterior apresentou problemas na saída da fumaça pela chaminé, sendo então desmontado. De fato, o madeiramento superior e as telhas localizadas bem acima daquele fogão estavam ainda enegrecidas de fumaça. No local onde havia o segundo fogão ainda observa-se os vestígios de um de seus lados em alvenaria rebocada, com a seguinte inscrição: "1.10.1949". Este fogão teria sido desmontado quando da construção de uma nova cozinha na parte externa do engenho, contígua à casa da moenda.

Junto às paredes laterais há vários objetos rejeitados. São barris de madeira, artefatos dos aparelhos de fazer farinha e de moer cana. Alguns destes objetos certamente não permanecerão ali num eventual abandono do engenho, sendo vendidos para algum colecionador.

14 BORRERO; YACOBACCIO, op. cit., p. 26. 


\section{2 - A cozinha e a dieta habitual}

A cozinha é um dos espaços mais utilizados no engenho, principalmente por quem se ocupa do preparo da comida. Ali são realizadas as quatro refeições diárias que Alaíde e Chico ainda denominam como os antigos colonizadores: de manhã cedo é hora do "café"; as 10 horas é a vez do "almoço", que pode incluir um café com pirão e peixe; entre meio dia e 13 horas é a hora da "janta", geralmente a refeição principal do dia, composta de pirão, carnes, peixes e verduras; as 18 horas acontece a última refeição do dia, a "ceia", uma refeição leve, geralmente com alguma coisa que sobrou durante o dia. Os alimentos que não são produzidos no engenho, são comprados ou trocados na localidade mais próxima. As trocas geralmente são feitas obedecendo-se o valor comercial do produto. Assim, quatro quilos de farinha de mandioca equivalem aproximadamente a 1 quilo de lingüiça; 5 litros de cachaça equivalem a 5 quilos de açúcar e 5 quilos de arroz. Embora a farinha seja produzida somente nos meses de junho e julho, Chico dispõe de um estoque que lhe dá condiçôes de consumo e de troca durante todo o ano.

Na pequena área da cozinha - 9 metros quadrados - está assentado o fogão, construído com tijolos argamassados e reboco liso. Possui altura de 1 metro e base retangular de 1 metro por 70 centímetros. Sobre ele há uma chapa de ferro onde são colocadas as panelas para cozimento. A lenha utilizada como combustível é apanhada nas imediações e armazenada no engenho, a maioria em local próprio.

Na parte lateral do fogão, Alaíde passa parte do tempo que espera pelo cozimento da comida, de pé e levemente debruçada sobre ele, ajeitando a lenha ao fogo. Como o piso da cozinha também é de "chão-batido", ela produziu uma leve concavidade sob seus pés, com superfície um pouco mais lisa que o restante da cozinha.

Há ainda uma mesa retangular de madeira para refeições, servida por dois bancos também de madeira, dispostos a ela lateralmente. No piso abaixo dos bancos há um leve alisamento produzido pelo movimento dos pés de quem está sentado à mesa.

Compõem a cozinha ainda, dois armários de madeira com prateleiras, onde são guardados alguns alimentos industrializados e utensílios modernos. As evidências de adaptação aos tempos modernos apresentam-se com mais intensidade na cozinha. Há também uma pia com água encanada, utilizada para lavar louças. 


\section{3-O depósito de lenha}

Contígua à cozinha e incorporada à construção original, há uma área utilizada para depósito de lenha. Ali é mantido um estoque de lenha, para eventuais períodos longos de chuva. Serve também como "garagem" do carro de bois, muito utilizado antigamente para transportar mandioca e cana de açúcar das roças até o engenho. Atualmente é utilizado somente para cargas muito pesadas. Chico prefere carregar os molhos de cana nos ombros, pois o uso do carro necessitaria em alguns casos, duas pessoas.

\section{4 - A casa do alambique}

O local onde se encontra o alambique, foi construído posteriormente. Encontra-se a 1 metro e meio abaixo da casa da moenda e sob o mesmo teto. Antes funcionava num espaço ao lado, mas que se tornou muito pequeno para o número de pessoas que ali trabalhavam.

O alambique é composto por um forno circular de 1 metro e meio de diâmetro, por um enorme tacho com o mesmo diâmetro do forno e uma boca estreita $(40 \mathrm{~cm})$ e pelo capacete, na parte superior do conjunto. Está assentado num canto formado pelas paredes lateral e frontal. A boca do forno situa-se ao nível do chão.

O capacete, também chamado "cachimbo", é feito de cerâmica, possuindo um afunilamento no tubo horizontal. Este tubo encaixa-se num cano de cobre imerso em água corrente num cocho de madeira de dois metros e meio de comprimento. Os vapores alcoólicos que desprendem do caldo fermentado em ebulição condensam-se e transformam-se em cachaça sendo coletados na outra extremidade do cano por um pote de cerâmica com capacidade para 6 litros. No chão onde é colocado o pote há uma depressão de 40 centímetro de diâmetro com profundidade de 5 centímetros na parte mais profunda, produzida pelo movimento de colocá-lo e retirá-lo no local onde escorre a cachaça destilada. Esta operação é repetida até 5 vezes em cada "alambicada". ${ }^{15}$

A cachaça é armazenada em 2 tonéis de plástico com capacidade de 50 litros cada. Antigamente era armazenada em barris de madeira,

15 "Alambicada" é o nome dado no engenho para as etapas do processo de destilação da cachaça. 
mas estes são raros hoje em dia e deterioram-se ou perdem a qualidade com determinado tempo de uso, o que fez o proprietário optar por vasilhames de plástico, mais resistentes e duráveis.

\section{5 - A casa de moradia}

A casa de moradia é composta por uma "varanda", ${ }^{16}$ dois quartos e uma sala. Esta parte possui arquitetura diferente dos demais espaços. Apesar de fazer parte da construção original, foi toda reformada, já faz algum tempo. Segundo informações do proprietário, uma de suas irmãs se casaria e seu pai então ofereceu uma festa no engenho, utilizando-se da reforma para melhor recepcionar os convidados. As paredes externas foram refeitas, de tijolos e argamassa com reboco claro, as portas e janelas em meia-folha com madeira beneficiada-no restante do engenho as aberturas foram feitas de tábuas brutas - e introduzido um assoalho de tábuas planas em todos os cômodos. A cobertura tradicional de telhas capa e canal foi substituída por telhas francesas.

Em cada quarto há uma cama e algumas caixas de madeira, usadas para guardar roupas e pequenos objetos. Na varanda, há um baú, um armário, vários balaios e alguns garrafões vazios. Na sala há uma cama, um baú e grande quantidade de feijão com casca, depositada ali para secar.

\section{6 - Áreas desativadas no engenho}

A desativação da produção de açúcar, criou algumas áreas obsoletas, embora estejam sendo utilizadas para outros fins Nestas se enquadram os espaços das caldeiras, da boca dos fornos e do alambique antigo.

Parte do espaço destinado às caldeiras está sendo usado para a coleta e fermentação do caldo da cana em dois cochos de madeira, sobrepostos e ligados ao moedor de cana por um cano subterrâneo. A área da bocas dos fornos é usada para criar porcos. O local onde havia o alambique antigo é usado apenas para depósito de materiais descartados que Chico não dispensa por achar que mais tarde terão uma nova função

16 Entre as pessoas que ainda mantêm costumes mais antigos é comum designar a sala de estar por "varanda". 
de uso. Estes materiais encontram-se em todo o engenho, embora concentrem-se mais nas áreas acima. Para uma visão geral da disposição dos materiais descartados ou não no engenho, ver mapa 3.

\section{7 - Áreas de circulação}

As áreas de circulação no engenho do Chico, possuem frequiência diferenciada de acordo com as atividades específicas, realizadas em cada espaço. Estas são realizadas permanentemente no mesmo local. Não podem compartilhar seu espaço com outro tipo de atividade. Se a cozinha emprestar sua área para cortar e depositar lenha, deixará de ser cozinha, pois não terá espaço para suas atividades específicas, preparar e cozer alimentos. Do mesmo modo, não será possível fazer comida no depósito de lenha porque lá o espaço estará tomado pela lenha. ${ }^{17}$ Apesar de estarem interligadas (para cozer alimentos é preciso lenha e parte da lenha exista no engenho para abastecer o fogão) estas duas atividades possuem frequêencia distintas no seu desenvolvimento. Na cozinha há alta freqüência de circulação e no depósito de lenha baixa freqüência. Para melhor compreensão da freqüência em áreas internas, foi adotado o seguinte esquema:

Baixa freqüência de circulação - até 3 vezes por dia Média frequêencia de circulação - até 6 vezes por dia Alta freqüência de circulação - mais de 6 vezes por dia

A cozinha possui alta freqüência, por ser a área doméstica mais utilizada no engenho. Os acessos a ela são também áreas de grande circulação. Na casa da moenda, a área junto ao moedor possui alta freqüência somente nos dias que a cana é moída, duas vezes por semana. Nos outros dias, passa a ser área de baixa circulação, porque é o caminho de acesso à casa de moradia, para onde se dirige pouco durante todo o dia. A variação ocorre porque a cozinha não está ligada à casa de moradia. No restante da área da casa da moenda, a freqüência é alta porque possui acesso para a cozinha e para o exterior.

17 BINFORD, L. R. En busca del pasado. Barcelona: Editorial Crítica, 1983. p. 198. 


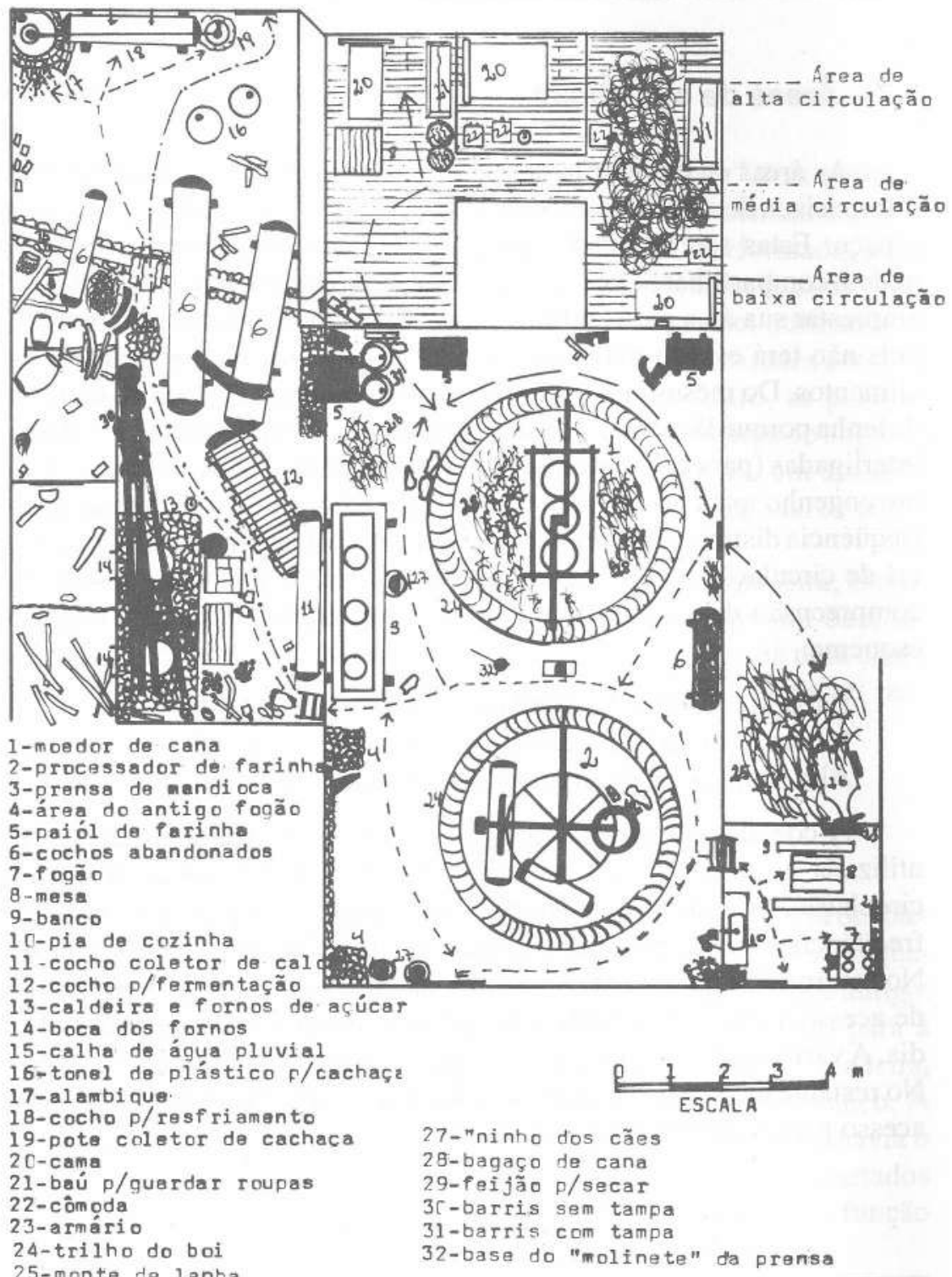

25-monte de lenha

26-carro de bois 
Nas áreas próximas e de acesso ao alambique, a frequêencia de circulação é alta nos dias de destilação da cachaça. Nos outros dias, apresenta baixa circulação, porque é ali que se guarda a cachaça destilada.

Ao depósito de lenha vai-se em média duas vezes por dia, para buscar lenha para o fogão ou para o forno do alambique.

\section{4 - O ESPAÇO EXTERNO}

\section{1 - 0 entorno}

O entorno do engenho do Chico não possui a mesma diversificação de atividades ocorrida no espaço interno, mas possui também sua organização espacial voltada para o desenvolvimento das poucas tarefas especializadas ali existentes. Se no espaço interno há uma estrutura organizacional montada, vital para o desenvolvimento das atividades produtivas e domésticas, no entorno a organização se apresenta de forma imprescindível, porém mais simplificada e mais voltada para as atividades domésticas. Estas também necessitam de especialização, mas não requerem necessariamente uma divisão. Com exceção da atividade de lavar roupa, tida como exclusivamente feminina, as outras são executadas por Alaíde e eventualmente, por Chico: cuidar dos animais domésticos, capinar e semear uma pequena horta, cortar lenha e varrer a área próxima à entrada principal do engenho.

O entorno é a área onde a deposição arqueológica melhor se evidencia. São quatro montes de lixo com conteúdos diversos, resultado das varreduras periódicas do espaço interno e do próprio entorno. Entre estes locais de deposição secundária, há materiais descartados com significativa abundância (ver mapa 4).

Em entonos de sítios históricos, é comum a presença de restos de construção como fragmentos de telhas e tijolos, pedras, pregos e restos de madeira e de reboco. São o resultado de sucessivas reformas arquitetônicas devido tanto à decomposição dos materiais construtivos quanto à ampliação e reorganização do espaço interno. O engenho do Chico também passou por essas reformas e ampliações e os restos de materiais construtivos acham-se espalhados numa área defronte à fachada frontal. 


\section{2 - A roça no contexto paisagístico}

No início do século XVIII, a ilha era quase toda coberta por vegetação primária não havendo mais do que 15 sítios de habitações dispersos por toda a sua superfície, segundo dados de viajantes que por ali passaram naquele século. ${ }^{18}$ Com a implantação da colonização açoriana a partir de 1748, o governo português distribui terras em forma de lotes aos novos colonos para ali se estabelecerem como agricultores. As terras eram ocupadas e parte da sua vegetação derrubada para a construção de casas, de móveis, de embarcações, na utilização como combustíveis e sobretudo para a abertura de roças. Estas eram as que mais impacto causavam na vegetação, pois extensas áreas tinham de ser derrubadas e queimadas para dar lugar às culturas necessárias à subsistência do povo. Para piorar o problema, havia uma rotatividade considerável das áreas agrícolas, devido à baixa fertilidade natural do solo. As terras eram utilizadas para as lavouras de mandioca e cana de açúcar principalmente, até a exaustão. Em seguida, novas áreas eram retomadas até que a antiga recuperasse sua fertilidade. Este processo era natural, sem qualquer utilização de adubos. Por isso, cada área de antigas roças podia levar aproximadamente 20 anos até sua reutilização. Quando as roças já se situavam longe dos engenhos, estes eram reconstruídos próximos às novas áreas de plantio.

Estas técnicas agrícolas ainda são utilizadas na sua plenitude no engenho do Chico. Num dos dias de visita ao engenho, uma área estava sendo retomada para se transformar em uma roça de cana. Esta área foi abandonada uns 18 anos atrás, segundo o proprietário, e reutilizada sem qualquer adubação artificial. Como ele dispõe de uma área considerável de terras, ainda é possível selecionar o solo a ser plantado, sem muito prejuízo nas colheitas.

As encostas e morros da ilha de Santa Catarina possuem um tipo de solo chamado "podzólico vermelho-amarelo", não apropriado para práticas agrícolas. ${ }^{19}$ Nas terras pertencentes ao engenho do Chico, é possível visualizar com facilidade as marcas da rotatividade do solo. São numerosas áreas de antigas roças, com tamanho e tipo de vegetação

18 ILHA DE SANTA CATARINA. Relato de Viajantes estrangeiros nos séculos XVIII e XIX. 2. ed. Florianópolis: UFSC/Assembléia Legislativa do Estado de Santa Catarina, 1984. p. 23, 46.

19 CARUSO, op. cit., p. 25. 
ENTCRNO - AREAS DE CIRCULAÇXO

DISTRIBUIÇAO DR VEGETAÇAC

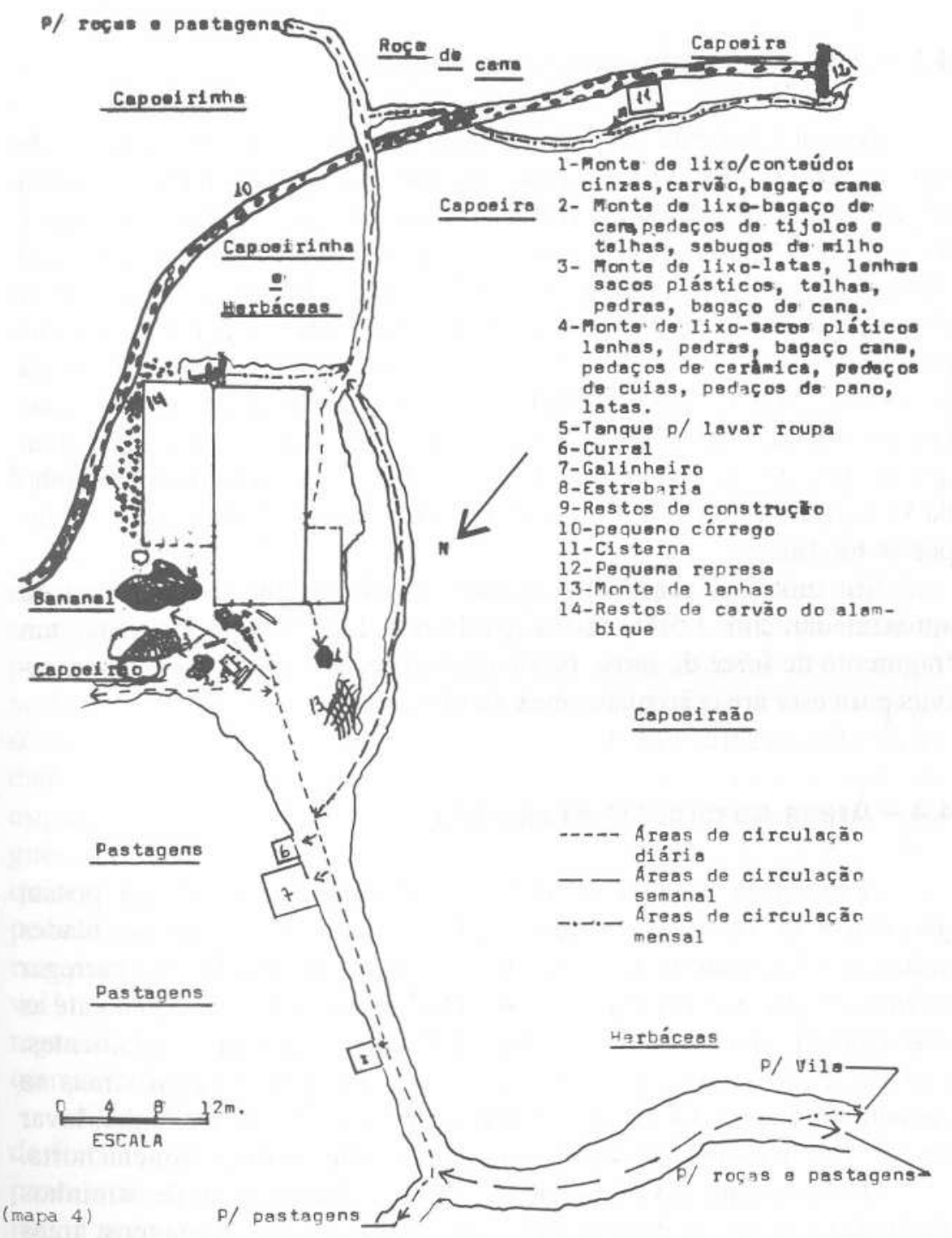


diferentes, com tonalidades que vão do verde-claro ao verde-escuro, na busca de seu clímax.

\section{3 - A roça no contexto arqueológico}

A roça é por excelência, uma extensão do universo de trabalho de um engenho e o local onde ocorre intensa atividade humana. É onde a relação homem-trabalho atinge seu auge de dispêndio de energia e tempo. Em contrapartida, há na roça, raros vestígios da acumulação arqueológica da cultura material. Não se tem conhecimento de qualquer obra relevante de contenção em roças com terrenos acidentados que possam deixar vestígios da atividade humana. Por outro lado, a presença de carvão oriundo das queimadas não reflete aspectos materiais, mas apenas indícios de identificação de áreas de lavouras que já foram queimadas. Antigas roças podem ser também detectadas pelo tamanho da vegetação, que pode levar aproximadamente 120 anos para recompor-se totalmente.

Em uma das roças do engenho, recém capinada, com área de aproximadamente 1.500 metros quadrados, foi encontrado apenas um fragmento de foice de ferro. Neste caso específico, as evidências materiais para esta área são quase inexistentes.

\section{4 - Áreas de circulação externa}

A exemplo da área interna do engenho, a área externa possui freqüência de circulação diferenciada, de acordo com as atividades desenvolvidas. Entretanto, uma área de circulação usada para carregar molhos de cana por exemplo, serve também para conduzir o gado até as pastagens, porque as atividades por ali desenvolvidas não permanentes. Elas caracterizam-se mais como áreas de acesso, embora próximas ao engenho situem-se locais de atividades fixas, como cortar lenha, lavar roupas, criar pequenos animais domésticos e manter uma pequena horta.

O entrelaçamento das áreas de circulação forma a rede de caminhos existentes no entorno do engenho. Conduzem às roças, pastagens, áreas de obtenção de lenha e regiōes vizinhas.

O esquema utilizado para mostrar a circulação em áreas internas não se adapta às áreas externas, porque estas possuem em alguns casos, 
freqüência de uma ou duas vezes por mês. Assim, podem ser sistematizadas em freqüência diária, semanal e mensal. Para as roças em colheita ou em manutenção, Chico dirige-se até 5 vezes por dia. O mesmo acontece em direção às pastagens próximas do engenho. Já para fora dos limites do engenho, geralmente a localidade mais próxima, onde ele adquire alguns gêneros alimentícios, a freqüência é semanal. Para as áreas de plantio que não estão em manutenção ou em época de colheita, a freqüência passa a ser mensal. A visita a elas é tida apenas como uma "vistoria". O mesmo acontece com o sistema de captação d'água do córrego, em situação normal. Assim, a freqüência de circulação em caminhos de acesso às roças está condicionado ao ciclo agrícola. Quando as roças são abandonadas, a circulação nas áreas próximas normalmente também é abandonada.

\section{5 - CONCLUSÃO}

Os engenhos de farinha de mandioca, de açúcar e os alambiques movimentaram a economia da Ilha de Santa Catarina por mais de dois séculos. Possuem grande importância na história de Santa Catarina, mais precisamente de Florianópolis, embora não sejam tratados como tal. A acelerada decadência de que foram vítimas a partir da metade deste século originou-se num processo irreversível de modernização da sociedade florianopolitana. Entretanto, modernizações à parte, parece que esquece-se da história. Os pobres e fragmentados engenhos foram entregues à própria sorte. Mas eles não desapareceram completamente. Daqueles que só restam vestígios, a arqueologia se encarregará deles. Dos poucos que ainda funcionam, e que apresentam grande potencial de compreensão dos meios de exploração de recursos naturais, do desenvolvimento tecnológico, do relacionamento com o meio ambiente, das regras comportamentais de seus integrantes antes que desapareçam completamente.

Os trabalhos efetuados no engenho de Francisco Tomás dos Santos, de feições etnográficas, mostraram que é possível recompor partes de processos sociais, econômicos e culturais há muito desaparecidos. Para isto, é necessário compreender as relações do homem com a natureza e com suas próprias criações. $\mathrm{O}$ equilíbrio existente entre eles possibilita o nosso entendimento de como há duzentos anos passados iniciou-se um processo de colonização que para os dias de hoje seriam considerados 
absurdos. Uma colonização que optou pelo bem estar de seus integrantes a qualquer preço, extraindo da natureza grandes quantidades de áreas verdes em troca de roças que a curto prazo se tornariam improdutivas. Indiferença ou não às questôes ambientais, seus descendentes criaram um sistema produtivo capaz de mantê-los e de criar um excedente de exportação e uma convivência pacífica com a natureza, que não parou de fornecer-lhes o que dela precisavam.

\section{REFERÊNCIAS BIBLIOGRÁFICAS}

AZEVEDO, Esterzilda B. de. Arquitetura do açúcar. Sāo Paulo: Nobel, 1990.

BINFORD, L. R. En busca del pasado. Barcelona: Editorial Crítica, 1983.

BORRERO L. A.; YACOBACCIO, H. D. Etnoarqueología de asentamientos Aché. In: Journal de la Société des Américanistes. Buenos Aires: 1989.

CABRAL, Oswaldo R. Os açorianos. Florianópolis: Imprensa Oficial, 1950.

CARUSO, Mariléa M. L. O desmatamento da ilha de Santa Catarina de 1500 aos dias atuais. 2. ed. Florianópolis: UFSC, 1990.

FLORIANÓPOLIS. Lei Municipal $n^{\circ} 1202$, de 2.4.74. IPUF, datilografada.

GAMITO, Teresa J. Aldeia dos Mouros versus Alcaria Queimada: an ethnoarchaeological case study. In: —. Arqueologia hoje I. Faro: Universidade do Algarve, 1990. p. 266.280.

ILHA DE SANTA CATARINA. Relato de viajantes estrangeiros nos séculos XVIII e XIX. 2. ed. Florianópolis: UFSC/Assembléia Legislativa de Santa Catarina, 1984.

PEREIRA, Nereu do V. A origem e a tecnologia do engenho de farinha da ilha de Santa Catarina. In: Anais da Segunda Semana de Estudos Açorianos. Florianópolis: UFSC, 1984.

PIAZZA, Walter F. A mandioca e a sua farinha. Florianópolis: Faculdade Catarinense de Filosofia, 1956.

VÁRZEA, Virgílio. Santa Catarina, a Ilha. Florianópolis: IOESC, 1984. 